\title{
Extension of lifespan of graphite in fuel blocks of high-temperature gas-cooled reactors as the resource for ensuring design values of nuclear fuel burn-up*
}

\author{
Olga I. Bulakh ${ }^{1}$, Oleg K. Kostylev ${ }^{1}$, Vladimir N. Nesterov ${ }^{1}$, Eldar K. Cherdizov ${ }^{1}$ \\ 1 Engineering School of Nuclear Technology «National Research Tomsk Polytechnic University», 30 Lenin str., Tomsk, 634050, Russia \\ Corresponding author: Olga I. Bulakh (o.i.kataeva@gmail.com)
}

Academic editor: Yury Kazansky • Received 04 July 2019 • Accepted 30 September 2019 • Published 10 December 2019

Citation: Bulakh OI, Kostylev OK, Nesterov VN, Cherdizov EK (2019) Extension of lifespan of graphite in fuel blocks of hightemperature gas-cooled reactors as the resource for ensuring design values of nuclear fuel burn-up. Nuclear Energy and Technology 5(4): 289-295. https://doi.org/10.3897/nucet.5.48391

\begin{abstract}
High-temperature gas-cooled reactor (HTGR) is one of promising candidates for new generation of nuclear power reactors. This type of nuclear reactor is characterized with the following principal features: highly efficient generation of electricity (thermal efficiency of about 50\%); the use of high-temperature heat in different production processes; reactor core self-protection properties; practical exclusion of reactor core meltdown in case of accidents; the possibility of implementation of various nuclear fuel cycle options; reduced radiation and thermal effects on the environment, forecasted acceptability of financial performance with respect to cost of electricity as compared with alternative energy sources.

The range of output coolant temperatures in high-temperature reactors within the limits of $750-950{ }^{\circ} \mathrm{C}$ predetermines the use of graphite as the structural material of the reactor core and helium as the inert coolant. Application of graphite ensures higher heat capacity of the reactor core and its practical non-meltability.

Residence time of reactor graphite depends on the critical value of fluence of damaging neutrons (neutrons with energies above $180 \mathrm{keV}$ ). In its turn, the value of critical neutron fluence is determined by the irradiation temperature and flux density of accompanying gamma-radiation. The values of critical fluence for graphite decrease within high-temperature region of $800-1000{ }^{\circ} \mathrm{C}$ to $1 \cdot 10^{22}-2 \cdot 10^{21} \mathrm{~cm}^{-2}$, respectively. The compactness of the core results in the increase of the fracture of damaging neutrons in the total flux. These circumstances predetermine relatively low values of lifespan of graphite structures in high-temperature reactors.

Design features and operational parameters of GT-MHR high-temperature gas-cooled reactor are described in the present paper. Results of neutronics calculations allowing determining the values of damaging neutron flux, nuclear fuel burnup and expired lifespan of graphite of fuel blocks were obtained. The mismatch between positions of the maxima in the dependences of fuel burnup and exhausted lifespan of graphite in fuel blocks along the core height is demonstrated.

The map and methodology for re-shuffling fuel blocks of the GT-MHR reactor core were developed as the result of analysis of the calculated data for ensuring the matching between the design value of the fuel burnup and expected total graphite lifespan.
\end{abstract}

\section{Keywords}

Critical fluence, reactor-grade graphite, damaging neutrons, graphite lifespan, nuclear fuel burnup, GT-MHR, HTGR

* Russian text published: Izvestiya vuzov. Yadernaya Energetika (ISSN 0204-3327), 2019, n. 3, pp. 40-52.

Copyright Olga I. Bulakh et al. This is an open access article distributed under the terms of the Creative Commons Attribution License (CC-BY 4.0), which permits unrestricted use, distribution, and reproduction in any medium, provided the original author and source are credited. 


\section{Introduction}

Development and implementation of new generation of nuclear reactors recognized in pursuance with IAEA classification as the safest reactor types are the promising direction of development of nuclear industry. One of such types of advanced nuclear reactors are the high-temperature gas-cooled reactors (HTGR) (Grebennik et al. 2008). Application of TRISO nuclear fuel and use of graphite as the structural material of the reactor core are the distinguishing technological features of HTGR reactors. Irradiation of graphite with damaging neutron flux resulting in the deformation of crystalline structure and development of defects takes place in the process of NPP operation (Goncharov et al. 1978; Platonov and Chugunov 2003; Tsyganov et al. 2007; Mochalov et al. 2015). As the result, physical, thermal physics and strenGTh properties of graphite serving as the main structural material of the reactor fuel block undergo significant deterioration.

Research conducted in the field of investigation of functionality of reactor-grade graphite in Russia is directed towards finding the solution of the main problem of objective interpretation of already existing experience of graphite operation in commercial and power uranium-graphite reactors for the purpose of application of graphite in the design of advanced nuclear reactors of HTGR type. The second problem in order of importance is the development of principles for handling graphite irradiated in uranium-graphite reactors.

\section{GT-MHR reactor}

GT-MHR reactor (Gas Turbine - Modular Helium Reactor) is one of the promising candidates aspiring for leadership among the new generation of HTGR nuclear reactors satisfying safety requirements put forward in the XXI century. Reactor facility consists of two interconnected blocks - modular gas-cooled reactor (MHR) and direct-cycle gas turbine power conversion unit (GT). The following constitutes the main principal features of the reactor (Ran et al. 1989; Kodochigov et al. 2006; Grebennik et al. 2008; IAEA-TECDOC-1694 2013; Mohammadkhani et al. 2014; Sahin et al. 2016):

- Highly efficient energy generation (thermal efficiency of about $50 \%$ );

- Use of high-temperature heat for different production purposes;

- Self-protection properties of reactor core, as well as the impossibility of core meltdown in case of accident;

- Possibility of implementation of different options of reactor fuel cycle (uranium-plutonium, thorium-uranium);

- Reduced radiation and thermal impact on the environment;

- Forecasted acceptability of financial performance indicators as pertains to the cost of generation of electricity as compared with alternative energy sources.
Implementation of GT-MHR reactor allows resolving numerous problems of nuclear power generation, as well as enhancing competitiveness of nuclear power plants (Ran et al. 1989; Grebennik et al. 2008). Extension of application of nuclear power generation to the area of commercial high-temperature technologies and expansion of the scope of countries-users of nuclear energy is one of the most important features of the project.

\section{Design and main performance parameters of GT-MHR reactor}

Cross-section of the reactor core is the hexagonal collar consisting of 1020 hexagonal prismatic fuel blocks arranged in 102 columns of 10 fuel blocks each. Fuel blocks are shaped in the form of hexagonal graphite prism with elements containing nuclear fuel inserted in the channels bored through the block (IAEA-TECDOC-1238 2001; La Bar et al. 2003; Chen et al. 2009). Fuel blocks have channels for passage of coolant and loading burnable neutron absorber. Fuel block of the reactor core is represented in Fig. 1a.

Uranium dioxide with $U^{235}$ enrichment reaching 19.9\% distributed in the graphite matrix in the form of separate fuel microelements with four layers of coating made of pyrolytic carbon and silicon carbide is used as the fuel in the reactor core.

Cross-section of fuel microelement is shown in Fig. $1 \mathrm{~b}$.

Each fuel block incorporates 198 fuel channels containing press-fitted fuel microelements. Uranium load per one fuel block amounts to $4.25 \mathrm{~kg}$. Density of graphite in the matrix of fuel elements and fuel blocks is equal to $1.7 \mathrm{~g} / \mathrm{cm}^{3}$.

Main characteristics of collar-shaped reactor core are represented in Table 1 (Nesterov 2013).

\section{Variation of fluxes damaging and thermal neutrons during fuel residence in the reactor core}

Determination of neutron flux spectrum in the reactor core was performed by solving the set of multi-group neutron diffusion equations by iterative method. The iterative method was implemented within the framework of multi-group calculation using the methodology described in (Golovatsky et al. 2010b).

All group values and, consequently, the values averaged over the spectrum to be entered in the expression for determination of effective neutron multiplication factor $k_{\text {eff }}$ were determined based on the partial neutron flux values obtained (Golovatsky et al. 2010a; Shamanin et al. 2017). Thus, the value of $k_{\text {eff }}$ at the beginning of fuel irradiation amounted to 1.144 taking into account the burnable neutron absorber. 

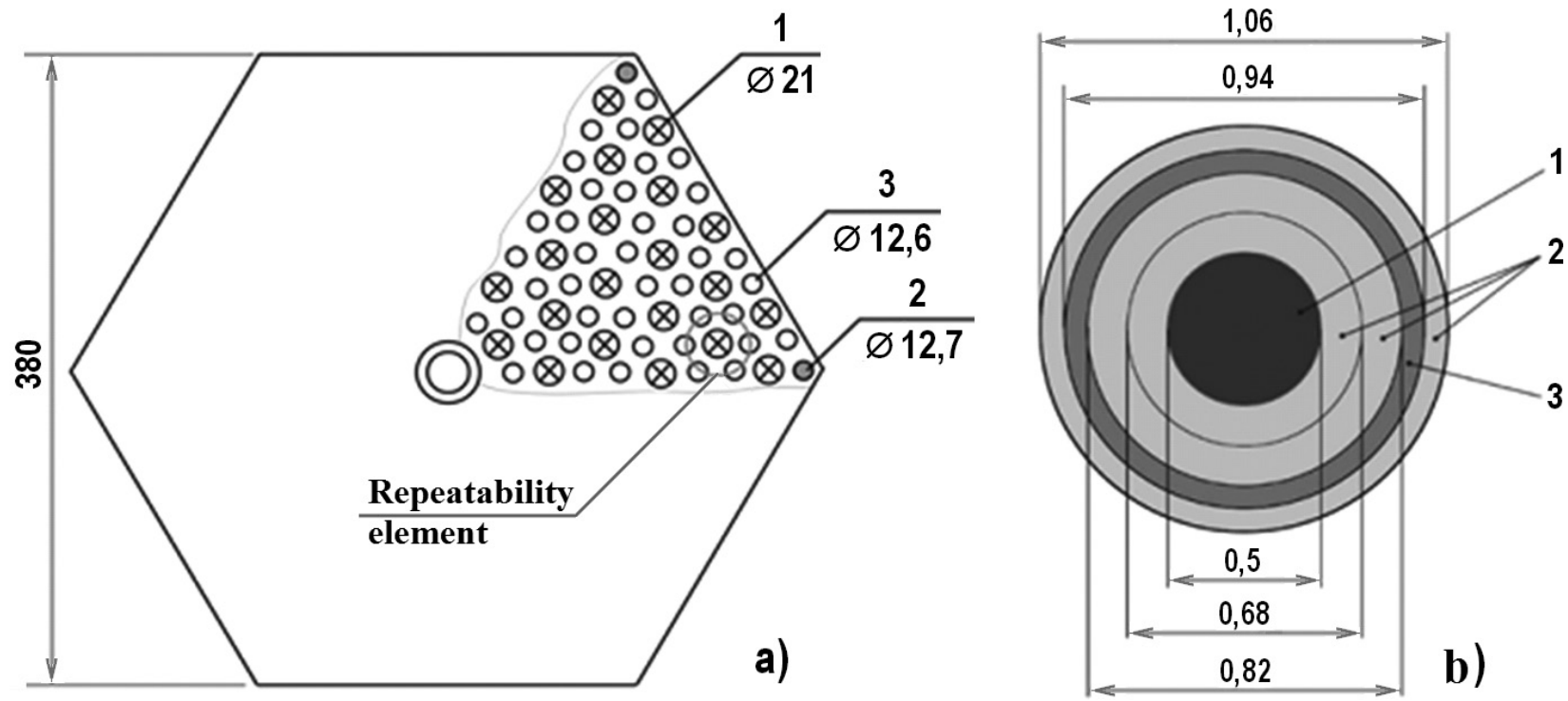

Figure 1. a). Fuel block of GT-MHR reactor core: 1 - channel for coolant passage; 2 - channel for burnable neutron absorber; 3 fuel channel. b). Design of fuel microelement: 1 - uranium dioxide; 2 - pyrolytic graphite; 3 - silicon carbide.

Table 1. Main characteristics of GT-MHR reactor (Nesterov 2013).

\begin{tabular}{|c|c|}
\hline Characteristic & Value \\
\hline Thermal power of the reactor core, MW & 600 \\
\hline Internal equivalent diameter, $\mathrm{m}$ & 2.96 \\
\hline External equivalent diameter, $\mathrm{m}$ & 4.84 \\
\hline Core height, $\mathrm{m}$ & 7.92 \\
\hline Average specific power yield, $\mathrm{MW} / \mathrm{m}^{3}$ & 6.6 \\
\hline Number of fuel columns in the reactor core & 102 \\
\hline Number of fuel blocks in the column & 10 \\
\hline Uranium load per one fuel block, $\mathrm{kg}$ & 4.25 \\
\hline $\mathrm{U}^{235}$ enrichment, $\%$ & $\begin{array}{l}\text { Up to } 19.9 \\
(14-\text { average } \\
\text { for the core })\end{array}$ \\
\hline $\begin{array}{l}\text { Burnable neutron absorber (natural boron) load per } \\
\text { each of the six rods in the fuel block, } g\end{array}$ & $1.13 \div 2.25$ \\
\hline $\begin{array}{l}\text { Interval between core reloading and re-shuffling, eff. } \\
\text { days }\end{array}$ & 540 \\
\hline Fuel residence in the core, eff. days & 1080 \\
\hline Maximum fuel burnup, $\mathrm{MW} \cdot$ days $/ \mathrm{t}_{\mathrm{U}}$ & $1.4 \cdot 105$ \\
\hline $\begin{array}{l}\text { Maximum reactivity margin in cold non-poisoned state } \\
\text { in the process of fuel residence campaign, } \% \delta \mathrm{k} / \mathrm{k}\end{array}$ & 12.5 \\
\hline Temperature reactivity effect, $\% \delta \mathrm{k} / \mathrm{k}$ & $<4.9$ \\
\hline Maximum specific power density of the core, $\mathrm{W} / \mathrm{m}^{3}$ & $<23$ \\
\hline Efficiency of 48 pairs of control rods on $5 \mathrm{~m}$ run, $\% \delta \mathrm{k} / \mathrm{k}$ & $>14$ \\
\hline Reactor core poisoning with Xe, $\% \delta \mathrm{k} / \mathrm{k}$ & $>2.6$ \\
\hline $\begin{array}{l}\text { Efficiency of } 18 \text { channels of spherical reactivity } \\
\text { compensation system, } \% \delta \mathrm{k} / \mathrm{k}\end{array}$ & $>8.2$ \\
\hline Coolant pressure, $\mathrm{MPa}$ & 7.07 \\
\hline Temperature, core inlet / outlet, ${ }^{\circ} \mathrm{C}$ & $490 / 850$ \\
\hline $\begin{array}{l}\text { Maximum permissible fuel temperature in normal } \\
\text { operational conditions (w/o accounting for fuel } \\
\text { overheating factors), }{ }^{\circ} \mathrm{C}\end{array}$ & 1250 \\
\hline $\begin{array}{l}\text { Maximum permissible fuel temperature during } \\
\text { accidents, }{ }^{\circ} \mathrm{C}\end{array}$ & $<1600$ \\
\hline Number of reactivity compensation rods & 54 \\
\hline $\begin{array}{l}\text { Number of channels of redundant reactivity } \\
\text { compensation system }\end{array}$ & 18 \\
\hline
\end{tabular}

Maximum reactivity margin in cold, non-poisoned conditions amounts in this case to $\rho=12.6 \%$ in the course of fuel residence in the reactor core. The obtained value of reactivity margin practically coincides with the design value $(\rho=12.5 \%)$ which demonstrates satisfactory quality of the calculation.

Evolution of nuclide composition of nuclear fuel in the process of its irradiation can result in significant variation of values of fluxes of damaging and thermal neutrons, which will affect the expected service life graphite. Variation of concentrations of the following nuclides: $\mathrm{U}^{235}$, $\mathrm{U}^{238}, \mathrm{Pu}^{239}, \mathrm{Pu}^{240}, \mathrm{Pu}^{241}, \mathrm{Pu}^{242}$, products of fission of $\mathrm{U}^{235}$ and $\mathrm{Pu}^{239}$ is taken into account in the present study (Golovatsky et al. 2010a; Baybakov et al. 2016).

Dependences of fluxes of thermal and damaging neutrons on nuclear fuel burnup are presented in Fig. 2.

Bred fissionable plutonium nuclides possess high neutron absorption and fission cross-sections in thermal energy region and, besides that, average number of secondary fast neutrons per one fission event is higher than that for $\mathrm{U}^{235}$. This leads to the increased hardness of neutron flux spectrum in the course of irradiation of nuclear fuel, as the result of which damaging neutron flux density by the end of fuel residence in the core is practically by four times higher than that for fresh fuel.

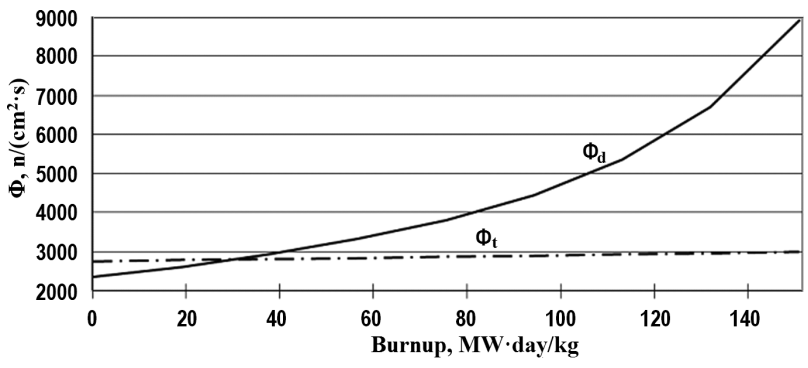

Figure 2. Dependences of fluxes of thermal $\Phi_{t}$ and damaging $\Phi_{d}$ neutrons on the nuclear fuel burnup 


\section{Temperature of irradiation and service life of graphite}

In order to estimate service life of graphite it is necessary to determine the distribution of graphite irradiation temperature over the reactor core, because it is the decisive factor influencing the value of critical fluence of damaging neutrons. Non-uniformities of temperature distribution and the accumulated fluence of damaging neutrons over the reactor core result in the significant changes of local volumes of graphite and serve as one of the main causes of deformation and destruction of fuel.

Axial distribution of power release within fuel column was preset in accordance with (Sedov and Frolov 2010).

Minimum value of heat release in the fuel along the core height amounted to $44 \%$, which corresponds to the numerical value equal to $4.17 \mathrm{MBT} / \mathrm{M}^{3}$. Maximum value of heat release amounted to $9.49 \mathrm{MW} / \mathrm{m}^{3}$.

Elementary cell with radius equal to $R_{\mathrm{el}}$ was chosen for the determination of temperature field within the fuel block (Fig. 3).

The elementary cell and heat release profile allow determining the field of graphite irradiation temperatures by applying the standard methodology of thermal physics calculations (Boyko et al. 2005).

The value of "expired lifespan" is used in (Golovatsky et al. 2011; Nesterov 2013) for the determination of the degree of preservation of operational characteristics of graphite. The value of expired lifespan as the fraction of total lifespan is determined by the following relation:

$$
\mathrm{EL}=F / F_{\mathrm{cr}},
$$

where $F$ is the accumulated fluence of damaging neutrons with energies in excess of $0.18 \mathrm{MeV} ; F_{\text {cr }}$ is the value of

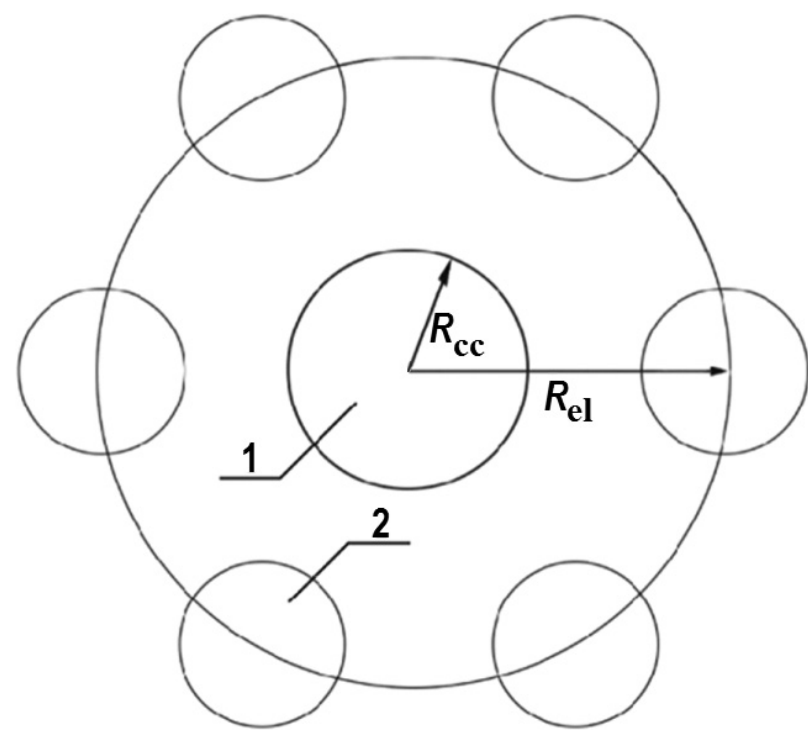

Figure 3. Elementary cell of reactor core with radius $R_{\mathrm{el}}=2,46$ $\mathrm{cm}$ for the determination of temperature field: 1 - coolant channel $R_{\mathrm{cc}}=1.05 \mathrm{~cm} ; 2$ - nuclear fuel channel $R_{\mathrm{nf}}=0.63 \mathrm{~cm}$ critical fluence of damaging neutrons depending on the graphite irradiation temperature.

If $E L \leq 1$, than it is recognized that the operational characteristics of graphite are still preserved. Irreversible changes of the operational characteristics, first of all deformation and, following this, crack formation accompanied by degradation of thermal physics properties can be expected for EL $>1$.

Duration of nuclear fuel residence in the core amounts to 1090 eff. days (two years of 545 eff. days each), on the basis of which calculation of the graphite expired lifespan was performed. Variation of power release over the core radius was not taken into account. Dependence of the expired lifespan of graphite over the core height is shown in Fig. 4 for radius $R_{\mathrm{el}}$, because this point is the farthest

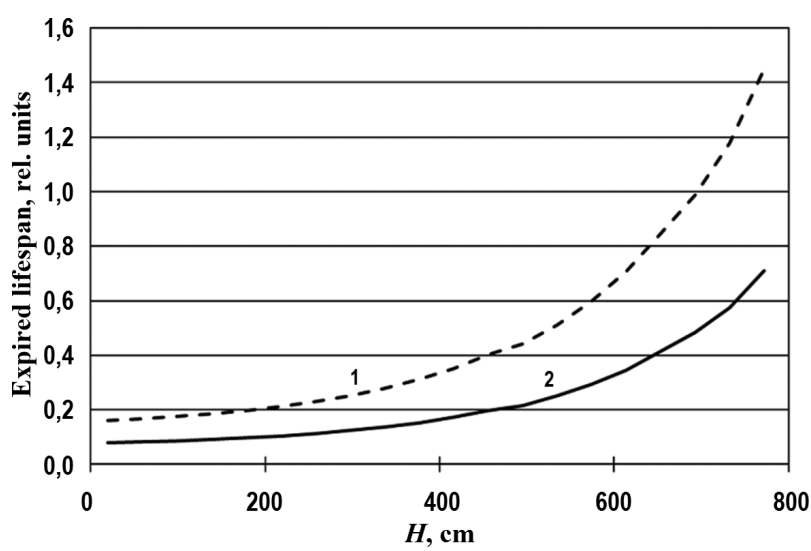

Figure 4. Time dependence of the expired lifespan of graphite along the core height: 1 - nuclear fuel residence time equal to 1090 eff. days; 2 - time between fuel re-shuffling in the core equal to 545 eff. days

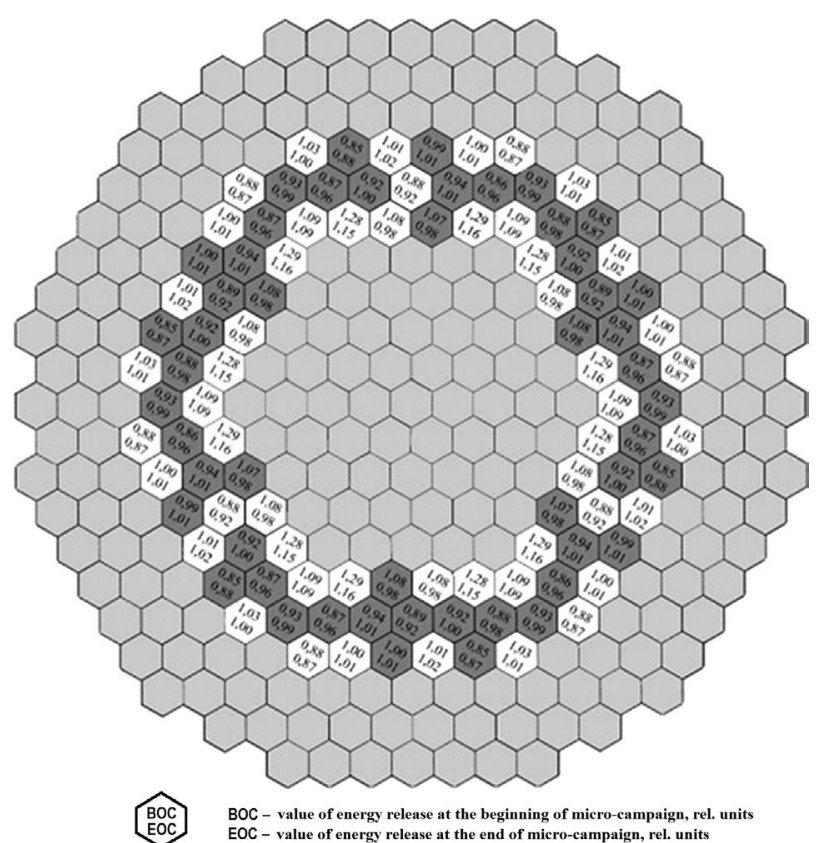

Figure 5. Map of GT-MHR reactor core: white - fuel assemblies after irradiation during the burnup cycle; gray - fresh fuel assemblies; graphite reflector at the periphery and in the center 

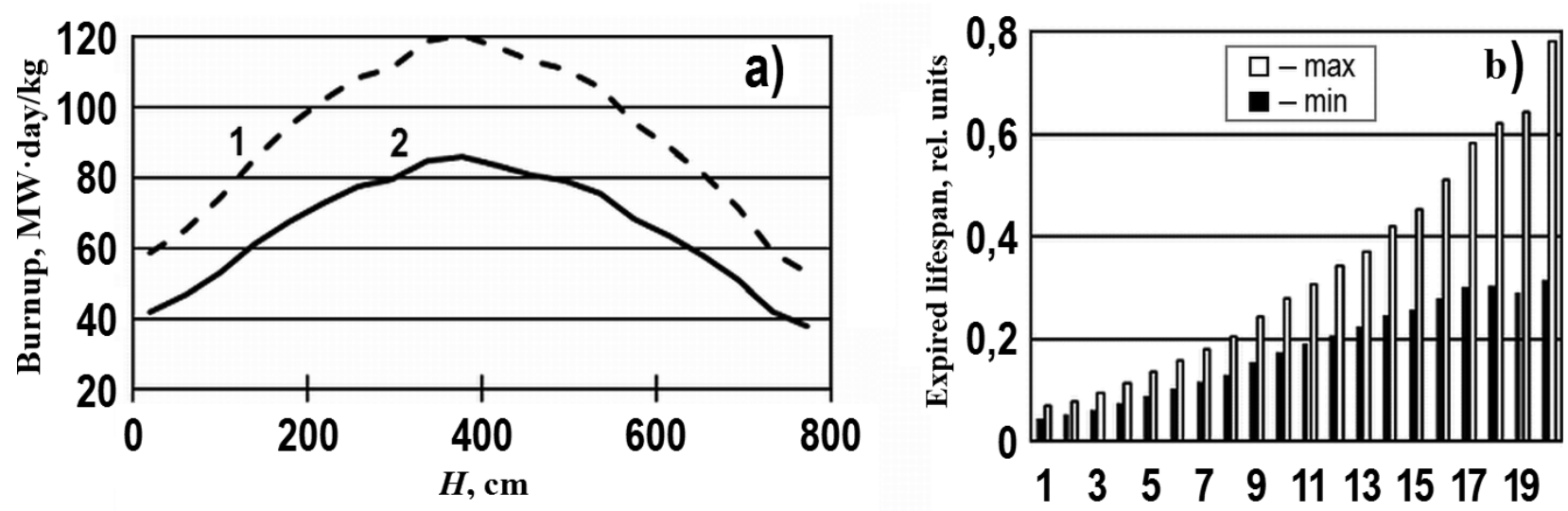

Figure 6. a). Dependence of burnup depth along the core height for fuel block at the end of nuclear fuel irradiation micro-campaign: 1 - maximum $k_{r}(1.23) ; 2$ - minimum $k_{r}(0.88)$. b). Expired lifespan of graphite at the end of nuclear fuel irradiation campaign for sections of fuel blocks with maximum (1.23) and minimum (0.88) $k_{r}$

removed from the coolant and, therefore, maximum temperatures are observed in it.

Calculated value of the expired lifespan exceeds unity by the end of nuclear fuel residence time in the core, which demonstrates the possibility of destruction of fuel block inside the reactor core. Maximum value of graphite lifespan already expired by the moment of fuel re-loading amounted to $71 \%$, and the minimum value was equal to $8 \%$. Therefore, fuel block must be necessarily moved at the moment of fuel re-shuffling and re-loading from dangerous sections to safe ones taking account the value of radial-azimuth heat-release non-uniformity factor. The data from (Sedov and Frolov 2010) using which the map of reactor core was plotted (Fig. 5) were used in the study of effects of radial and azimuth non-uniformity of heat release (hereinafter radial) over the reactor core.

Two cycles of nuclear fuel burnup are assumed in the reactor (Sedov and Frolov 2010). Time interval between fuel re-loading and re-shuffling operations is either referred to as the fuel irradiation micro-campaign or the burnup cycle. Two values of heat release are shown in the core map in each of the cells corresponding to the beginning and the end of fuel irradiation micro-campaign for different fuel assemblies (fuel blocks). It was accepted based on the duration of fuel residence time in the core, that energy yield at the beginning of micro-campaign with fresh fuel assemblies acts during the first year of reactor operation and, at the end of micro-campaign - during the second year; in the calculation of fuel assemblies during the second burnup cycle the beginning of fuel irradiation micro-campaign corresponds to the third year of reactor operation and its end corresponds to the fourth year.

Values of energy release are repeated for different sections of the core, based on which they are grouped, therefore, by the number of fuel blocks with similar values of non-uniformity factors and the year of irradiation. Values of expired graphite lifespan at the end of each nuclear fuel irradiation micro-campaign are of the utmost interest, since the sequence of re-shuffling of fuel blocks ensuring graphite serviceability and allo- wing achieving the design fuel burnup can be developed by analyzing these values.

Dependences of nuclear fuel burnup depth and expired lifespan of fuel blocks at the end of fuel irradiation micro-campaign along the height of fuel column with maximum $\left(k_{r}=1.23\right)$ and minimum $\left(k_{r}=0.88\right)$ radial energy release non-uniformity factors are presented in Fig. 6.

It is evident from the figure that radial non-uniformity over the reactor core significantly affects not only the fuel burnup, but, as well, the lifespan of fuel blocks. Irradiation of fuel blocks in the central part of the core results in the achievement of maximum fuel burnup, while the fuel in the upper and lower parts does not reach the intended burnup.

Examining the effects of arrangement of fuel blocks in the reactor core it is clear that with increase of temperature and radial non-uniformity of energy release the expired fraction of graphite lifespan increases and reaches the value of about 0.8 near the lower elevation mark of the core for maximum value of the heat-release non-uniformity factor. Continuation of use of graphite on these sections will lead to irreversible changes of operational characteristics, reduction of thermal conductivity and deformation of the blocks, since their expired lifespan will exceed the critical value already during the third year of irradiation of the fuel block.

Thus, the methodology of fuel blocks re-shuffling presented below (Fig. 7) is used for ensuring the design fuel burnup depth and preserving the graphite lifespan during the whole duration of fuel irradiation campaign.

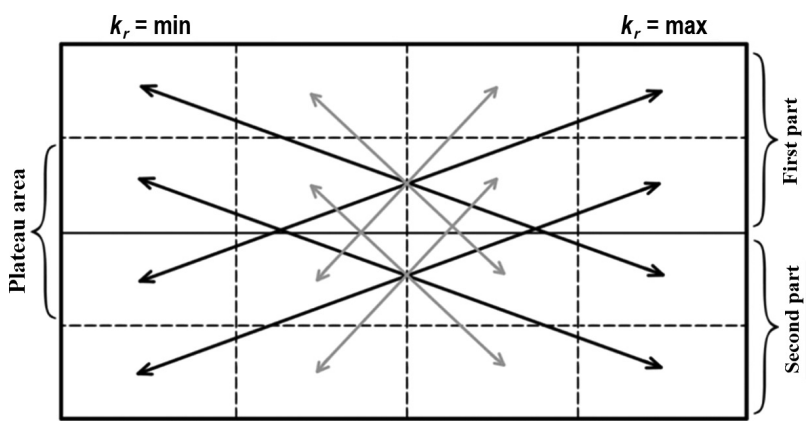

Figure 7. Diagram of re-shuffling graphite blocks 

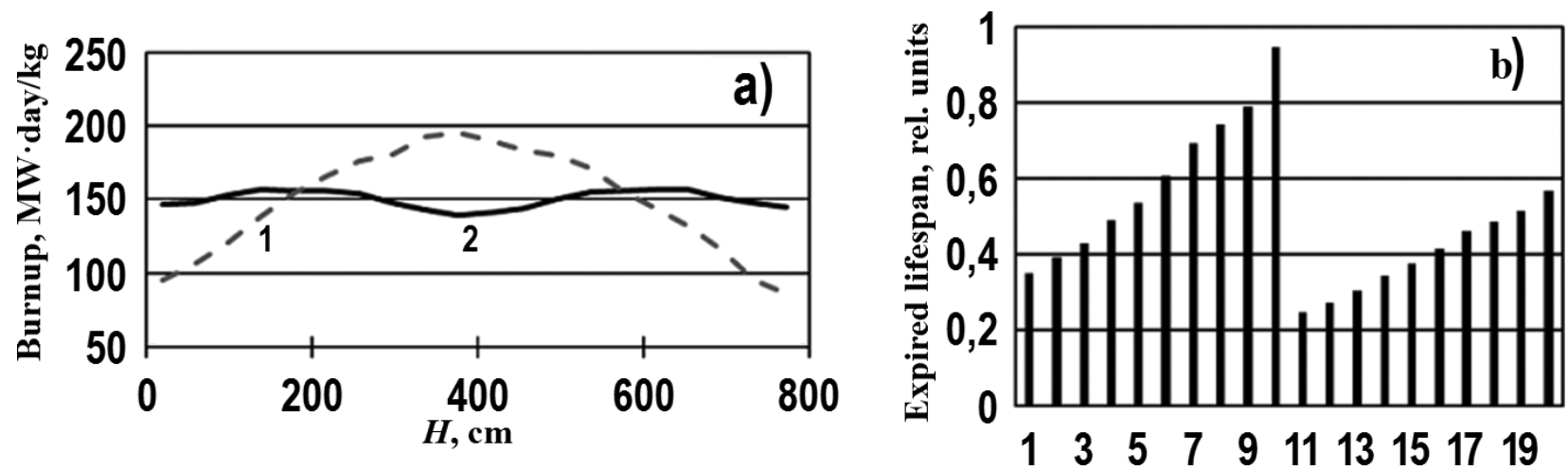

Figure 8. a). Dependence of burnup depth on the height of the reactor core at the end of nuclear fuel irradiation campaign: 1 - without taking re-shuffling of graphite blocks into account; 2 - taking re-shuffling of graphite blocks into account. b). Dependence of the value of expired lifespan of graphite along the core height at the end of reactor fuel irradiation campaign with different non-uniformity of heat release after re-shuffling the blocks at the middle of fuel irradiation campaign

Methodology of re-shuffling fuel blocks.

1. Reactor core is divided into two part along the height.

2. Fuel blocks from the periphery of the first (upper) part of the core from fuel columns irradiated in the conditions with high values of radial non-uniformity swap places with fuel blocks extracted from the heat release plateau area of the second (lower) part of the core and go to fuel columns irradiated in the conditions with low values of radial heat release non-uniformity.

3. Fuel blocks from the heat release plateau of the first (upper) part of the core from fuel columns irradiated in the conditions of high radial non-uniformity swap places with fuel blocks from the periphery of the second (lower) part of the core and go to fuel columns irradiated in the conditions of low radial heat release non-uniformity.

4. Fuel blocks from the periphery of the first (upper) part of the core from fuel columns irradiated in the conditions with low radial non-uniformity coefficients swap places with fuel blocks in the area of heat release plateau of the second (lower) part of the core and go to fuel columns irradiated with high radial heat release non-uniformity coefficients.

5. Fuel blocks from the area of heat release plateau of the first (upper) part of the core from fuel columns irradiated in the conditions of low radial heat release non-uniformity coefficients swap places with fuel blocks on the periphery of the second (lower) part of the core and go to fuel columns irradiated with high radial heat release non-uniformity coefficients.
Area of the plateau occupies the central part of the core along its height where the value of heat release is the closest to the maximum value.

The above combination is exercised for the whole reactor core, which allows levelling the heat release field, ensuring the design burnup depth, as well as extending service life of graphite in the GT-MHR reactor. Effects of re-shuffling fuel blocks is illustrated in Fig. 8.

\section{Conclusion}

Discrepancy between the maxima in the dependences of nuclear fuel burnup depths and expired lifespan of graphite of fuel blocks along the core height of GT-MHR reactor was demonstrated (see Fig. 6). This may result in the following events during the nuclear fuel irradiation campaign:

- Part of fuel block may be destroyed before the design value of nuclear fuel burnup depth is reached;

- Excess of the design value of nuclear fuel burnup depth occurs with serviceability of nuclear fuel retained;

- Neither the design value of nuclear fuel burnup depth nor the limiting value of expired lifespan of graphite are reached.

Layout and methodology of re-shuffling and re-loading fuel blocks of GT-MHR were developed as the result of analysis of calculated data for ensuring achieving the design value of nuclear fuel burnup depth by staying within the graphite expected service life.

\section{References}

- Baybakov DF, Godovykh AV, Martynov IS, Nesterov VN (2016) Influence of the nuclide composition of the fuel load on the multiplying and reproducing properties of the active zone of the KLT-40S reactor installation. Izvestiya vuzov. Yadernaya energetika 2: 99-111. [in Russian] https://doi.org/10.26583/npe.2016.2.10

- Boyko VI, Gavrilov MP, Koshelev FP, Meshcheryakov VN, Nesterov VN, Ratman AV, Shamanin IV (2005) Estimation of service life of graphite fuel blocks of the GT-MGR reactor. Izvestiya Tomskogo politekhnicheskogo universiteta 5: 81-84. [in Russian] 
- Chen F, Dong Y, Zheng Y, Shi L (2009) Benchmark Calculation for the Steady-State Temperature Distribution of the HTR-10 under Full-Power Operation. Journal of Nuclear Science and Technology 46(6): 572-580. https://doi.org/10.1080/18811248.2007.9711564

- Golovatsky AV, Nesterov VN, Shamanin IV (2010a) Effect of nuclear fuel composition and burnup on the effective value of the damaging neutrons flux in the GT-MGR reactor. Izvestiya Tomskogo politekhnicheskogo universiteta 4: 14-18. [in Russian]

- Golovatsky AV, Nesterov VN, Shamanin IV (2010b) The organization of the iterative process in the numerical reconstruction of the neutron spectrum in neutron multiplying system with graphite moderator. Izvestiya vuzov. Fizika, 53(11), iss. 2: 10-14. [in Russian]

- Golovatsky AV, Nesterov VN, Shamanin IV (2011) Optimum graphite operating temperature for ensuring the design depth of nuclear fuel burnup in the GT-MGR reactor. Izvestiya Tomskogo politekhnicheskogo universiteta 2: 71-76. [in Russian]

- Goncharov VV, Burdakov NS, Virgil'ev YuS, Karpuhin VI, Platonov PA (1978) The Effects of Irradiation on Nuclear Reactor Graphite. Moscow. Atomizdat Publ., 272 pp. [in Russian]

- Grebennik VN, Kukharkin NE, Ponomarev-Stepnoy NN (2008) High-Temperature Gas-Cooled Reactors as the Innovative Direction in the Development of Nuclear Energy. Moscow. Energoatomizdat Publ., 136 pp. [in Russian]

- IAEA-TECDOC-1238 (2001) Gas turbine power conversion systems for modular HTGRs. International Atomic Energy Agency, Vienna, 209 pp.

- IAEA-TECDOC-1694 (2013) Evaluation of high temperature gas cooled reactor performance: Benchmark analysis related to the PBMR-400, PBMM, GT-MHR, HTR-10 and the ASTRA critical facility, International Atomic Energy Agency, Vienna, 688 pp.

- Kodochigov N, Sukharev Yu, Marova E, Mitenkova E, Novikov N (2006) Features of calculation of temperature reactivity coefficient in the GT-MHR reactor. III-rd Intern. Topical Meeting on High Temperature Reactor Technology. Johannesburg, South Africa, 1-4 Oct., Paper C00000173, CD. 9: 31-42.

- La Bar MP, Shenoy AS, Simon WA, Campbell EM (2003) The Gas Turbine Modular Helium Reactor. Nuclear News. Oct., 28 pp.
- Mochalov AM, Naymushin AG, Nesterov VN, Pugachev DK (2015) Determination of the accumulation rate of Wigner's stored energy in graphite moderator. Izvestia Vysshikh Uchebnykh Zawedeniy. Yadernaya Energetika 4: 101-111. [in Russian] https://doi.org/10.26583/ npe.2015.4.11

- Mohammadkhani F, Shokati N, Mahmoudi SMS, Yari M, Rosen MA (2014) Exergoeconomic assessment and parametric study of a Gas Turbine-Modular Helium Reactor combined with two Organic Rankine Cycles. Energy 65: 533-543. https://doi.org/10.1016/j.energy.2013.11.002

- Nesterov VN (2013) Ensuring the design value of the burn-up depth of nuclear fuel of high-temperature gas-cooled reactors by the extension of operability of reactor graphite. Izvestia Vysshikh Uchebnykh Zawedeniy. Yadernaya Energetika 2: 133-142. [in Russian] https:// doi.org/10.26583/npe.2013.2.16

- Platonov PA, Chugunov OK (2003) Radiation damage of graphite and the problem of extending the service life of graphite stack in high-power pressure tube reactor. Proc. of the VII-th International Conference on Reactor Materials. Dimitrovgrad, 95-114. [in Russian]

- Ran F, Adamantiades A, Kenton J, Brown Ch (1989) Nuclear Energy Directory. Moscow. Energoatomizdat Publ., 752 pp. [in Russian]

- Sahin S, Erol O, Sahin HM (2016) Investigation of a gas turbine-modular helium reactor using reactor grade plutonium with Th232 and U-238. Progress in nuclear energy 89: 110-119. https://doi. org/10.1016/j.pnucene.2016.02.006

- Sedov AA, Frolov AA (2010) Computational study of the influence of some systematic factors on the fuel temperature in an ultrahigh-temperature gas reactor with prismatic fuel assemblies. VANT. Ser. Fizika yadernykh reaktorov 3: 80-90. [in Russian]

- Shamanin IV, Bedenko SV, Nesterov VN, Lutsik IO, Prets AA (2017) Solution of the system of multigroup neutron transport equations in subcritical systems. Izvestiya vuzov. Yadernaya energetika 4: 38-49 [in Russian] https://doi.org/10.26583/npe.2017.4.04

- Tsyganov AA, Khvostov VI, Komarov EA, Kotlyarevsky SG, Pavlyuk AO, Shamanin IV, Nesterov VN (2007) Problems of utilization of reactor graphite of shut down industrial uranium-graphite reactors. Izvestiya Tomskogo politekhnicheskogo universiteta 2: 94-98. [in Russian] 